\title{
Effect of Fiber Length and Short Fiber Percent in Cotton on Fiber and Yarn Quality
}

\author{
Ibrahim A.E. Ibrahim ${ }^{1}$
}

\begin{abstract}
This study was carried out at Plant Production Department, Faculty of Agriculture (Saba Basha), Alexandria University, Egypt, during 2016 season to investigate the effect of fiber length and short fiber percent on fiber and yarn quality. In this work three cotton varieties namely: (Giza 88, Giza 86 and Giza 85) to represent the three categories of fiber length i.e., $(34.37$, 32.16 and $30.12 \mathrm{~mm}$ ) and three lint cotton grades from each cotton variety i.e., G/FG, G and FGF/G represent three categories of short fiber content $(4.50,5.30$ and 6.60 $\%)$. The studied treatments were arranged in completely randomized design (C.R.D.) with three replications.
\end{abstract}

The obtained results showed that the longest fibers $(34.37 \mathrm{~mm})$ significantly surpassed the others under study and gave the highest mean values of fiber bundle strength (g/tex), fiber stiffness, fiber toughness (g/tex), single yarn strength (cN/tex) and lea product and the lowest mean values for single yarn elongation (\%), yarn C.V. (\%), yarn unevenness $(\%)$ and hairiness. The lowest short fiber content $(4.50 \%)$ recorded the highest mean values for length uniformity (\%), fiber bundle strength (g/tex), fiber elongation (\%), fiber toughness (g/tex), single yarn strength (cN/tex), lea product, single yarn elongation (\%) and the lowest mean values for yarn C.V. (\%), yarn unevenness (\%) and hairiness.

In conclusion, to obtain the best quality of both fibers and yarns the longest cotton fibers with the lowest short fiber content should be used.

Key words: Cotton, Fiber length, Yarn, quality, Hairiness and Unevenness.

\section{INTRODUCTION}

Fiber length and its parameters are the most important components of cotton fiber quality because of its effects on the textile quality. Length and perimeters of fiber for the same cotton cultivar may vary from year to year at the same location (Meredith and Bridge 1973). Decreased fiber length affects yarn strength, hairiness, thin, thick and neps i.e., yarn imperfections. Yarn produced from shorter fibers has negative effect on yarn tenacity, hairiness and yarn imperfections (Parsi et al. 2016). The variations in fiber length distributions play important roles in predicting yarn properties, such as strength and irregularity. The best prediction model for the properties of different yarns (ring and open-end) includes different combinations of length parameters (Yiyun et al. 2013). Sevda and Kadoğlu (2006) reported that an increase in yarn linear density increases the hairiness. Secondly, fiber length is also another important parameter which influences hairiness, where increase in fiber length decreases hairiness. Also, the increase in the short-fiber percentage increase hairiness.

The quantity of short cotton fibers in a cotton sample is an important cotton quality parameter. It impacts yarn production efficiency and cost, and product quality (Backe 1986; Thibodeaux et al. 2008). The global cotton industry is increasingly interested in the characteristics of short fibers (Ethridge and Krifa, 2004). The quality of cotton yarns is directly affected by short fiber content. High short fiber also contributes to poor yarn tenacity and evenness, higher levels of imperfections, higher yarn hairiness and lower spinning efficiency (Stuart 2002).

American Standard Test Method (ASTM) defined the short fiber content (S.F.C.1/2"), as the percentage of fibers (by weight or number) shorter than $1 / 2$ inch. (ASTM D1440-07). Otherwise, the Chinese Standards Test Methods defined the short fiber content (S.F.C.16 $\mathrm{mm}$ ), as the percentage of fibers (by weight or number) shorter than $16 \mathrm{~mm}$. (Chinese Standards GB/T 6098.12006). Hager and Hassan (2016) reported that positive and highly significant association was observed between yarn hairiness and short fiber content. While the associations between yarn hairiness and the rest fiber properties (fiber length, fiber strength, micronaire, elongation and uniformity index were negative and significant or highly significant for all tested. Hanen et al. (2017) found that short fiber index and fiber strength have both significant effects on yarn strength but these two effects are opposite. Indeed, stronger fibers give stronger yarns. While, the shorter fibers are the weaker, the yarn becomes. So, the longer fibers are, the better evenness is.

\section{MATERIALS AND METHODS}

This study was carried out at Plant Production Department, Faculty of Agriculture (Saba Basha), Alexandria University, Egypt in 2016, to investigate the effect of three categories of fiber length $(34.37,32.16$

\footnotetext{
${ }^{1}$ Associate Prof., Plant Production Dept. Faculty of Agric. (Saba Basha), Alexandria

University, Egypt.

E-mail: dribrahimabbas@yahoo.com

Received November 18, 2018, Accepted December 06, 2018
} 
and $30.12 \mathrm{~mm}$ ) and short fiber contents (4.50, 5.30 and $6.60 \%)$ in raw lint cotton on fiber and yarn quality. Three cotton varieties (Giza 88, Giza 86 and Giza 85) were used to represent the three categories of fiber length. Three lint cotton grades from each cotton variety namely, G/FG, G and FGF/G were used to represent the three categories of short fiber content.

Yarn cotton was spun at 60s with 3.6 twist multiplier. Fiber and yarn quality were determined by using High Volume Instrument (H.V.I.) and Uster-tester, respectively in Cotton Research Institute, Spinning Research Department, Agricultural Research Center, Giza, Egypt, under standard atmospheric condition of $\left(20 \pm 2 \mathrm{C}^{\circ}\right)$ temperature and $(65 \% \pm 2 \%)$ relative humidity.

\section{The characters studied:}

\section{Cotton fiber quality:}

1.1. Length uniformity (\%).

1.2. Fiber bundle strength (g/tex).

1.3. Fiber elongation (\%).

1.4. Fiber stiffness (g/tex) was calculated according to the equation:

Fiber stiffness $=$ fiber strength $/$ fiber elongation $\times 100$

1.5. Fiber toughness (g/tex) was calculated according to the equation:

Fiber toughness $=$ fiber strength $x$ fiber elongation $/ 2$

2. Cotton yarn quality:

2.1. Yarn strength $(\mathrm{cN} / \mathrm{tex})$

2.2. Yarn elongation (\%)

2.3. Lea product

2.4. Yarn (C.V. \%)

2.5. Yarn unevenness (\%)

2.6. Yarn hairiness

\section{Statistical procedures:}

Completely randomized design with three repetitions was used. The attained data were statistically analyzed as a factorial experiment according to the procedure of Snedecor \& Cochran (1967). The least significant difference (L.S.D.) was calculated at 0.05 level of probability to estimate the significant differences between of treatment means.

\section{RESULTS AND DISCUSSION}

Data presented in Tables (1 and 2) showed mean values of fiber and yarn quality traits. The attained results in this research work will be presented and discussed herein in three categories as follows:

\section{Effect of fiber length on fiber and yarn quality:}

Results indicated that the effect of fiber length was significant on fiber strength (g/tex), elongation (\%), stiffness (g/tex) and toughness (g/tex) as shown in Table (1).
Furthermore, the highest mean values of fiber strength $(44.97 \mathrm{~g} / \mathrm{tex})$, fiber elongation $(6.71 \%)$, fiber stiffness $(675.92 \mathrm{~g} /$ tex $)$ and fiber toughness $(1.49 \mathrm{~g} / \mathrm{tex})$ were recorded with the longest fiber length $(34.37 \mathrm{~mm})$, while with $(30.12 \mathrm{~mm})$ for fiber elongation. Conversely, the lowest mean values $(39.16 \mathrm{~g} / \mathrm{tex}, 6.36 \%, 584.73$ $\mathrm{g} / \mathrm{tex}$, and 1.31) of the respective properties were recorded when used the shortest fiber length $(30.12 \mathrm{~mm})$ and with $(32.16 \mathrm{~mm})$ for fiber elongation.

In general trend there were a positive relationship between fiber length and mechanical fiber properties where increase fiber length led to increase the mechanical fiber properties. These results could be explained on the base that long staple cotton generally, had fine and strong fibers.

With respect to yarn quality data in Table (2) cleared that yarn quality under this study was significantly affected by fiber length.

It is worthy to mention that the longest fiber (34.37 $\mathrm{mm}$ ) recorded the highest mean values of single yarn strength (18.20 cN/tex) and lea product (2838.33) and in the same time the longest fiber recorded the lowest mean values of single yarn elongation $(4.12 \%)$, yarn C.V. (22.90\%), yarn unevenness (18.92\%) and yarn hairiness (3.98). Conversely, the shortest fiber $(30.12 \mathrm{~mm})$ gave the lowest mean values of both single yarn strength (13.75 cN/tex) and lea product (2181.66) and in the same time the shortest fiber recorded the highest mean values of single yarn elongation $(4.65 \%)$, yarn C.V. $(27.88 \%)$, yarn unevenness $(20.55 \%)$.

These results could be explained on the base that the tallest fiber is the finest and strongest. Additionally, the strength of the cotton yarns increases with increase the fiber length as result of increase the friction and bonding points along the length of the fiber during manufacturing.

Generally, increasing fiber length increased yarn strength and lea product and decreased single yarn elongation (\%), C.V.(\%), unevenness (\%) and hairiness and vice - versa.

These results agreed with those obtained by, Sevda and Kadoğlu (2006) who reported that the increase in fiber length decreases hairiness.

\section{Effect of short fiber content on fiber and yarn quality:}

Results in Table (1), it is obvious that the short fiber content had a significant effect on fiber uniformity (\%), single fiber strength (g/tex), fiber elongation (\%), and fiber toughness $(\mathrm{g} / \mathrm{tex})$ except, fiber stiffness (g/tex) which was insignificantly affected by short fiber content.

The fewest short fiber content i.e., $(4.50 \%)$ recorded the highest mean values for fiber uniformity $(87.10 \%)$, 
fiber strength (43.70 g/tex), fiber elongation $(6.80 \%)$, and fiber toughness $(1.48 \mathrm{~g} / \mathrm{tex})$. On the contrary, the highest short fiber content i.e., $(6.60 \%)$ recorded the lowest mean values for fiber uniformity $(84.50 \%)$, fiber strength (40.41 g/tex), fiber elongation $(6.24 \%)$, and fiber toughness $(1.26 \mathrm{~g} / \mathrm{tex})$.

These results could be explained on the base that the cotton fibers are more uniform and stronger when percentage of short fiber content in cotton is low.

In conclusion, increasing short fiber content up to $6.60 \%$ decreased fiber uniformity, fiber bundle strength, fiber elongation and fiber toughness, and vice versa.

Presented results in Table (2), it could be stated that the short fiber content had a significant effect on single yarn strength, lea product, single yarn elongation, yarn C.V., unevenness and hairiness.

From results tabulated in the same table it could be cleared that the highest mean values for single yarn strength (16.88 cN/tex), lea product (2575.00) and single yarn elongation $(4.47 \%)$ and lowest mean values for yarn C.V. (23.60 \%), yarn unevenness $(18.64 \%)$ and yarn hairiness (3.95) occurred when yarn spun from raw cotton fibers contains the lowest short fiber content (4.50\%). In contrast the lowest mean values for single yarn strength $(14.31 \mathrm{cN} /$ tex $)$, lea product (2249.44) and the highest mean values for yarn C.V. (27.30 \%), yarn unevenness (20.42\%) and yarn hairiness (4.41) resulted from the highest short fiber content $(6.60 \%)$, while the lowest mean values for yarn elongation (4.26 and 4.31 $\%)$ were recorded from short fiber content (5.30 and $6.60 \%)$, respectively.

In general, increasing short fiber content up to 6.60 $\%$ decreased the single yarn strength, single yarn elongation, lea product and increased yarn C.V. (\%), unevenness (\%) and hairiness.

These results agreed with those obtained by, Parsi et al. (2016), who found that yarn produced from shorter fibers has negative effect on yarn tenacity, hairiness and yarn imperfections. Also, agree with those obtained by Sevda and Kadoğlu (2006) they reported that increasing short-fiber percentage increase hairiness.

\section{Interactions between fiber length and short fiber content (A x B):}

Data in Tables $(1$ and 2$)$, cleared that $(\mathrm{A} \times \mathrm{B})$ interaction between the two studied variables, i.e. fiber length (A) and short fiber content (B) had significant effect on single yarn strength (cN/tex), yarn C.V.\% and yarn hairiness only.

Concerning the single yarn strength (cN/tex), it could be noticed that the highest mean value $(20.77 \mathrm{cN} / \mathrm{tex})$ was recorded for yarn spun from the longest fiber length $(34.37 \mathrm{~mm})$ with low short fiber contents $(4.50 \%)$, while the lowest mean value $(13.00 \mathrm{cN} /$ tex $)$ was attained when yarn spun from the shortest fiber length (30.12 $\mathrm{mm})$ with the highest short fiber content $(6.60 \%)$, as shown in Table (3).

Table 1. Mean values of fiber properties as affected by fiber length (A) short fiber content (B) and their interactions

\begin{tabular}{|c|c|c|c|c|c|}
\hline Treatments & $\begin{array}{c}\text { Fiber } \\
\text { uniformity (\%) }\end{array}$ & $\begin{array}{c}\text { Fiber } \\
\text { strength } \\
(\text { g/tex }) \\
\end{array}$ & $\begin{array}{c}\text { Fiber elongation } \\
(\%)\end{array}$ & $\begin{array}{c}\text { Fiber } \\
\text { stiffness } \\
(\mathrm{g} / \mathrm{tex}) \\
\end{array}$ & $\begin{array}{c}\text { Fiber toughness } \\
(\mathrm{g} / \mathrm{tex})\end{array}$ \\
\hline & \multicolumn{5}{|c|}{ Fiber length (mm) (A) } \\
\hline $34.37 \mathrm{~mm}$ & $85.75 \mathrm{a}$ & $44.97 \mathrm{a}$ & $6.66 \mathrm{a}$ & $675.92 \mathrm{a}$ & $1.49 \mathrm{a}$ \\
\hline $32.16 \mathrm{~mm}$ & $85.25 \mathrm{a}$ & $41.79 \mathrm{~b}$ & $6.36 \mathrm{~b}$ & $659.07 \mathrm{a}$ & $1.32 \mathrm{~b}$ \\
\hline $30.12 \mathrm{~mm}$ & $85.86 \mathrm{a}$ & $39.16 \mathrm{c}$ & $6.71 \mathrm{a}$ & $584.73 \mathrm{~b}$ & $1.31 \mathrm{~b}$ \\
\hline \multirow[t]{2}{*}{ L.S.D. 0.05} & NS & 1.46 & 0.26 & 28.26 & 0.08 \\
\hline & \multicolumn{5}{|c|}{ Short fiber content (\%) (B) } \\
\hline $4.50 \%$ & $87.10 \mathrm{a}$ & $43.70 \mathrm{a}$ & $6.80 \mathrm{a}$ & $644.14 \mathrm{a}$ & $1.48 \mathrm{a}$ \\
\hline $5.30 \%$ & $85.27 \mathrm{~b}$ & $41.83 \mathrm{~b}$ & $6.70 \mathrm{a}$ & $625.77 \mathrm{a}$ & $1.39 \mathrm{a}$ \\
\hline $6.60 \%$ & $84.50 \mathrm{~b}$ & $40.41 \mathrm{~b}$ & $6.24 \mathrm{~b}$ & $649.81 \mathrm{a}$ & $1.26 \mathrm{~b}$ \\
\hline L.S.D. 0.05 & 0.89 & 1.46 & 0.26 & N.S. & 0.08 \\
\hline $\mathbf{A} * \mathbf{B}$ & N.S. & N.S. & $\begin{array}{c}\text { Interaction } \\
\text { N.S. } \\
\end{array}$ & N.S. & N.S. \\
\hline
\end{tabular}

Means designated by the same letters within each column are not significantly different according to L.S.D. values at 0.05 level of probability. 
Table 2. Mean values of cotton yarn quality as affected by fiber length (A) short fiber content (B) and their interactions

\begin{tabular}{|c|c|c|c|c|c|c|}
\hline Treatments & $\begin{array}{l}\text { Single yarn } \\
\text { strength } \\
\text { (cN/tex) }\end{array}$ & $\begin{array}{c}\text { Lea } \\
\text { product }\end{array}$ & $\begin{array}{c}\begin{array}{c}\text { Single yarn } \\
\text { elongation }\end{array} \\
(\%)\end{array}$ & $\begin{array}{c}\text { Yarn C.V. } \\
(\%)\end{array}$ & $\begin{array}{c}\text { Yarn } \\
\text { Unevenness } \\
(\%)\end{array}$ & $\begin{array}{c}\text { Yarn } \\
\text { hairiness }\end{array}$ \\
\hline & \multicolumn{6}{|c|}{ Fiber length (mm) (A) } \\
\hline $34.37 \mathrm{~mm}$ & $18.20 \mathrm{a}$ & $2838.33 \mathrm{a}$ & $4.12 \mathrm{~b}$ & $22.9 \mathrm{c}$ & $18.92 \mathrm{~b}$ & $3.98 \mathrm{~b}$ \\
\hline $32.16 \mathrm{~mm}$ & $14.77 \mathrm{~b}$ & $2254.44 \mathrm{~b}$ & $4.26 \mathrm{~b}$ & $26.24 \mathrm{~b}$ & $18.95 \mathrm{~b}$ & $4.44 \mathrm{a}$ \\
\hline $30.12 \mathrm{~mm}$ & $13.75 \mathrm{c}$ & $2181.66 \mathrm{c}$ & $4.65 \mathrm{a}$ & $27.88 \mathrm{a}$ & $20.55 \mathrm{a}$ & $4.32 \mathrm{a}$ \\
\hline \multirow[t]{2}{*}{ L.S.D. 0.05} & 0.66 & 56.44 & 0.15 & 0.41 & 0.49 & 0.25 \\
\hline & \multicolumn{6}{|c|}{ Short fiber content (\%) (B) } \\
\hline $4.50 \%$ & $16.88 \mathrm{a}$ & $2575.00 \mathrm{a}$ & $4.47 \mathrm{a}$ & $23.60 \mathrm{c}$ & $18.64 \mathrm{c}$ & $3.95 \mathrm{~b}$ \\
\hline $5.30 \%$ & $15.54 \mathrm{~b}$ & $2450.00 \mathrm{~b}$ & $4.26 \mathrm{~b}$ & $26.12 \mathrm{~b}$ & $19.35 \mathrm{~b}$ & $4.38 \mathrm{a}$ \\
\hline $6.60 \%$ & $14.31 \mathrm{c}$ & $2249.44 \mathrm{c}$ & $4.31 \mathrm{~b}$ & $27.30 \mathrm{a}$ & $20.42 \mathrm{a}$ & $4.41 \mathrm{a}$ \\
\hline \multirow[t]{2}{*}{ L.S.D. 0.05} & 0.66 & 56.44 & 0.15 & 0.41 & 0.49 & 0.25 \\
\hline & \multicolumn{6}{|c|}{ Interaction } \\
\hline $\mathbf{A} * \mathbf{B}$ & $* *$ & N.S. & N.S. & $* *$ & N.S. & $* *$ \\
\hline
\end{tabular}

Means designated by the same letters within each column are not significantly different according to L.S.D. values at 0.05 level of probability.

Table 3. Interaction between fiber length and short fiber content $(A \times B)$ effect on single yarn strength, yarn C.V. and yarn hairiness

\begin{tabular}{|c|c|c|c|c|}
\hline \multicolumn{2}{|c|}{ Parameters } & \multirow{2}{*}{$\begin{array}{c}\text { Single yarn } \\
\text { strength }(\mathrm{cN} / \mathrm{tex})\end{array}$} & \multirow[b]{2}{*}{$\begin{array}{c}\text { Yarn C.V. } \\
(\%)\end{array}$} & \multirow[b]{2}{*}{ Yarn hairiness } \\
\hline $\begin{array}{c}\text { Fiber length (mm) } \\
\text { (A) }\end{array}$ & $\begin{array}{c}\text { Short fiber } \\
\text { content }(\%)(B)\end{array}$ & & & \\
\hline \multirow{3}{*}{$34.37 \mathrm{~mm}$} & 4.50 & $20.77 \mathrm{a}$ & $22.20 \mathrm{e}$ & $3.90 \mathrm{~b}$ \\
\hline & 5.30 & $18.26 \mathrm{~b}$ & $22.90 \mathrm{e}$ & $3.87 \mathrm{~b}$ \\
\hline & 6.60 & $15.28 \mathrm{c}$ & $23.60 \mathrm{de}$ & $4.16 \mathrm{~b}$ \\
\hline \multirow{3}{*}{$32.16 \mathrm{~mm}$} & 4.50 & $15.03 \mathrm{c}$ & $23.84 \mathrm{de}$ & $4.15 \mathrm{~b}$ \\
\hline & 5.30 & $14.93 \mathrm{c}$ & $26.81 \mathrm{c}$ & $4.94 \mathrm{a}$ \\
\hline & 6.60 & $14.36 \mathrm{c}$ & $28.07 \mathrm{~b}$ & $4.25 \mathrm{ab}$ \\
\hline \multirow{3}{*}{$30.12 \mathrm{~mm}$} & 4.50 & $14.83 \mathrm{c}$ & $24.76 \mathrm{~d}$ & $3.80 \mathrm{~b}$ \\
\hline & 5.30 & $13.43 \mathrm{c}$ & $28.66 \mathrm{~b}$ & $4.34 \mathrm{ab}$ \\
\hline & 6.60 & $13.00 \mathrm{c}$ & $30.23 \mathrm{a}$ & $4.82 \mathrm{ab}$ \\
\hline \multicolumn{2}{|c|}{ L.S.D. 0.05} & 1.96 & 1.22 & 0.75 \\
\hline
\end{tabular}

Means designated by the same letters within each column are not significantly different according to L.S.D. values at 0.05 level of probability.

Regarding yarn C.V. \%, it could be concluded that the highest percentage $(30.23 \%)$ resulted from the shortest fiber length $(30.12 \mathrm{~mm})$ with the highest short fiber content $(6.60 \%)$, while the lowest mean values (22.20 and $22.90 \%$ ) were recorded from the longest fiber $(34.37 \mathrm{~mm})$ with the lowest short fiber contents (4.50 and 5.30\%), respectively as shown in Table (3).

The highest mean value for the yarn hairiness (4.94) resulted from medium fiber length $(32.16 \mathrm{~mm})$ and short fiber content $(5.30 \%)$. As for the lowest mean value for the same character (3.80) it was obtained when yarn contain the shortest fiber length $(30.12 \mathrm{~mm})$ with the lowest short fiber content $(4.50 \%)$, as shown in Table (3).

In conclusion, using the longest fiber with the lowest short fiber content produced the strongest and regularity yarns.

\section{CONCLUSION}

In this work, it could be summarized that to produce the strongest fibers and yarns longest fiber length with the lowest short fiber content should be used.

\section{REFERENCES}

ASTM D1440-07: Standard test method for length and length distribution of cotton fibers (Array Method). ASTM Standards, Vol. 07.01.

Backe, E.E. 1986. Effect of short fiber content in cotton on plant performance and quality. Textile Res. J. 56(2):112115.

Ethridge, M.D., and M. Krifa. 2004. Renewed focus on short fibers. Textile Topics (3):1-8.

GB/T 6098.1-.2006. Test method for length of cotton fibers, roller analyser. National Standards of P.R. China. 
Hager, M. A. and A. A. Hassan.2016. Use of correlation and regression analysis in estimating relative importance of fiber properties affecting yarn hairiness in some Egyptian cotton genotypes. Int. J. Adv. Res. 4(8): 1274-1284.

Hanen, G., A. Ghith, T. Benameur.2017. Open-end yarn properties prediction using hvi fibre properties and process parameters. Autex Res. J., 17(1). http://www.autexrj.com/articles/515/516

Meredith, W.R., and R.R. Bridge.1973. Yield, yield component, and fiber property variation of cotton within and among environments. Crop Sci. 13:307-312.

Parsi, R. D., M. V. Kakde, K. Pawar and R. S. P. Patil. 2016. Influence of fiber length on ring spun yarn quality. Int. J. Res. and Scie. Innov. (IJRSI). 3(8): 154-156.

Sevda, A. and H. Kadoğlu. 2006. Determining fiber properties and linear density effect on cotton yarn hairiness in ring
sSpinning. FIBRES \& TEXTILES in Eastern Europe. 14(3): 57.

Snedecor, G.W. and W.G. Cochran. 1967. Statistical methods, 6 th ed. Iowa State Univ. Press. Ames. Iowa. USA.

Stuart, G. 2002. The effect of short fiber and neps on Murata vortex spinning. The Australian Cotton grower. 23(1): 28.

Thibodeaux, D., H. Senter, J. L. Knowlton, D. McAlister and X. Cui .2008. The impact of short fiber content on the quality of cotton ring spun yarn. J. cott. Sci., 12:368-377.

Yiyun C., X. Cui, J. Rodgers, D. Thibodeaux, V. Martin, M. Watson and S. Pang. 2013. A comparative study of the effects of cotton fiber length parameters on modeling yarn properties. Textile Res. J. 83(9): 961-970. 


\title{
الملخص العربي \\ تأثير طول الألياف ونسبة الثعيرات القصيرة فى القطن على جودة الألياف والخيط
}

\author{
إبراهيم عباس السبد إبرهيم
}

بالنسبة لتأثثر طول التيلة على صفات جودة الألياف

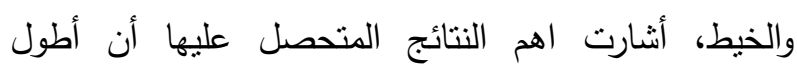

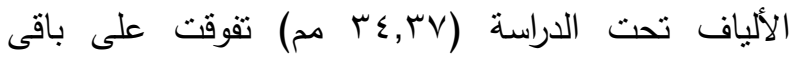
الأطوال المستخدمة وأعطت أعلى القيم لمتوسط كل من:

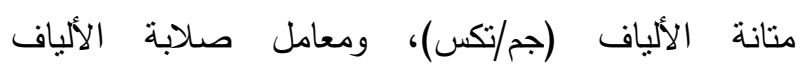
(جم/تكس)، قدرة الليفة على إمتصاص الجهد (جم/تكس)،

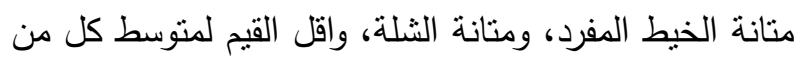
استطالة الخيط (\%)، ومعامل إختلاف الخيط (\%)، عدم (2)، إنتظامية الخيط (\%)، درجة التشعير بالمقارنة بالأطوال الأخرى تحت الدراسة. أما بالنسبة لتأثير نسبة الشعيرات القصبرة على صفات

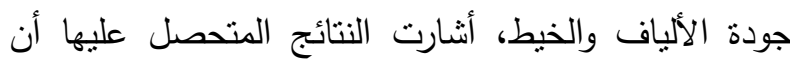

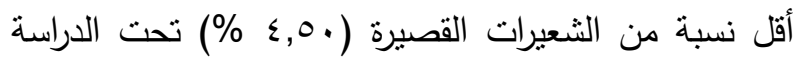

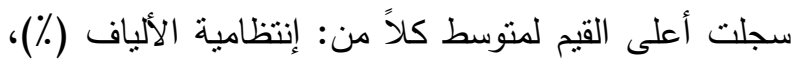
متانة الألياف (جم/تكس)، ومعامل صلابة الألياف (جم/تكس)، قدرة الليفة على إمتصاص الجهذ (جم/تكس)، ومنانة وإسنطالة الخيط المفرد، ومنانة الثلة، واقل القيم لمتوسط كلاً من: معامل إختلاف الخيط (\%)، عدم إنتظامية الخيط (\%)، درجة التشعير. مما سبق يمكن إستخلاص أن أفضل صفات الجودة للألياف والخيط يتم الحصول عليها عند إستخدام الألياف الطويلة ذات المحتوى الأقل من نسبة الثعيرات القصيرة.
تمت هذه الدراسة بقسم الإنتاج النباتي (المحاصبل) كلية الزراعة - (سابا باشا)، جامعة الإسكندرية، مصر ، خلال

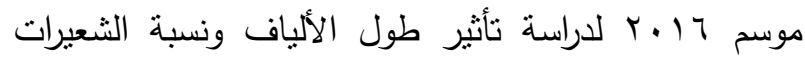
القصيرة على الصفات الميكانيكية والإنتظامية للألباف وصفات الجودة في خيوط الغزل. تم إستخدام ثلاثة أصناف

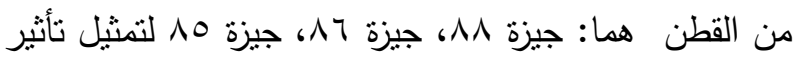
الثلاث مجموعات من طول التيلة المستخدمة فى الدراسة

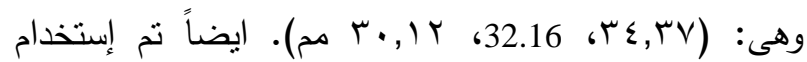
ثلاث رتب من القطن الشعر من كل صنف وهى: جود/فولى

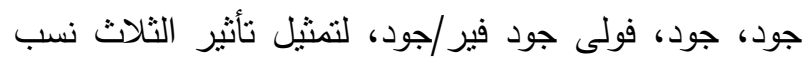

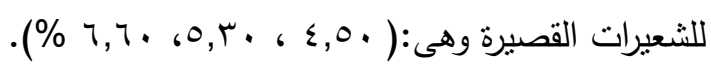

تم غزل العينات بنظام الغزل الحلقى ( Ring spinning (system بإستخدام نمرة خيط •T إنجليزى على معامل برم 7,r، وتم تقدير كل من: صفات جودة الألياف بإستخدام جهاز HVI طراز Spectrum II وصفات جودة الخيط بإستخدام جهاز الجود براند (Good-brand lea tester) لتقدير متانة الثلة (LeaProduct)، وكذلك تم تقدير كل من منانة Uster) وإستطالة وإنتظامية الخيط بإستخدام جهاز اليوسنرة (Tester III الزراعية بالجيزة تحت الظروف القياسية من درجة الحرارة

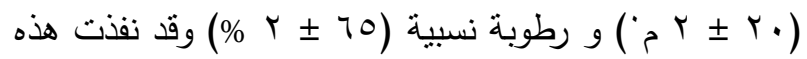
الدراسة العاملية فى تصميم تام العشوائية كررت فيه المعاملة

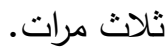

